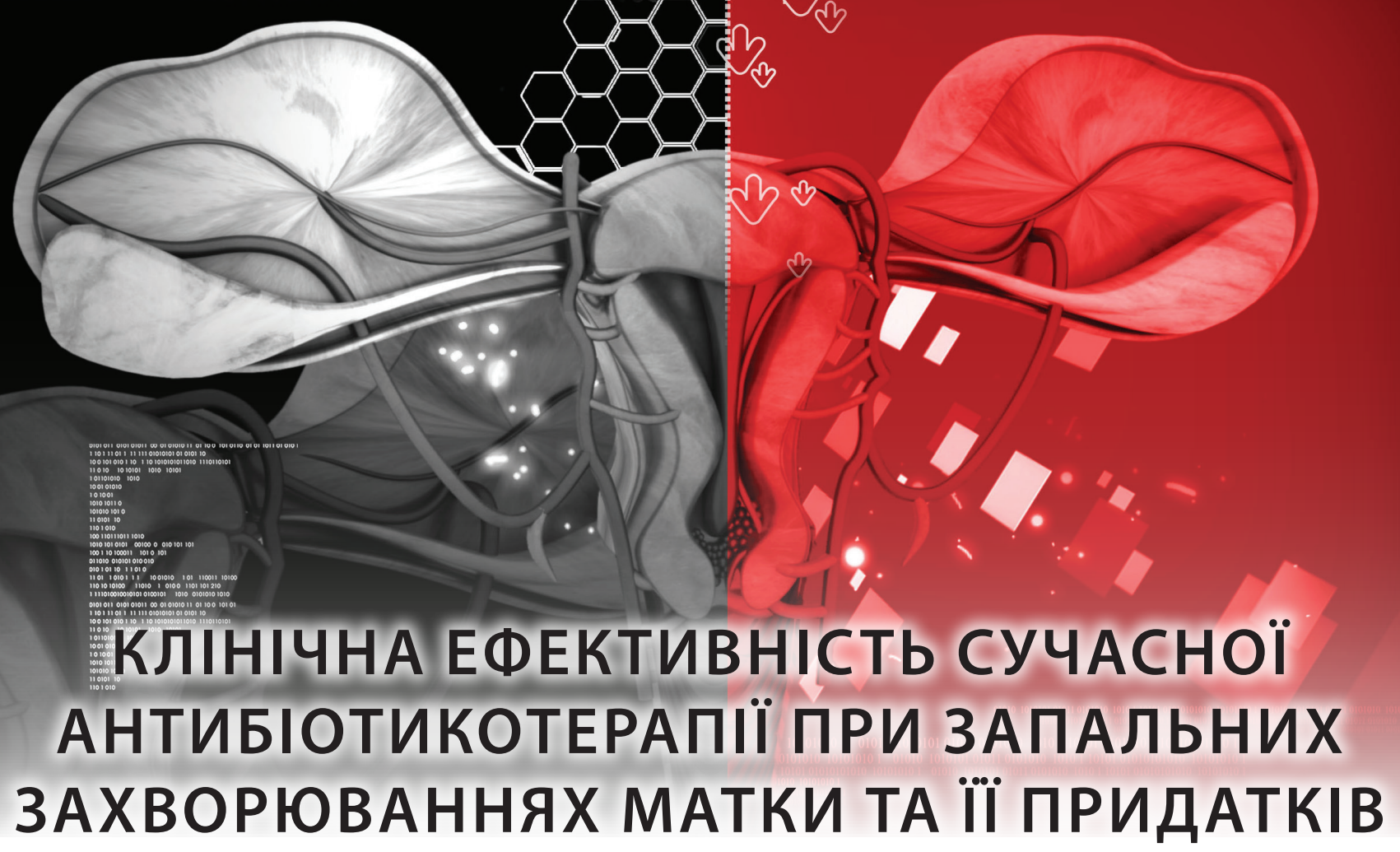

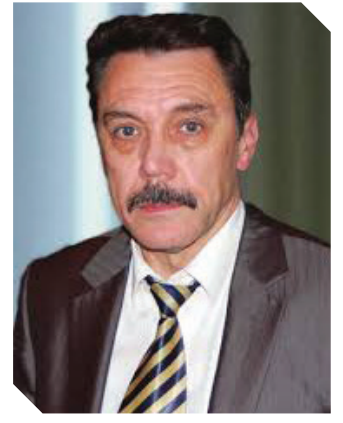

О.В. голяновСьКИЙ

д. мед. н., професор кафедри акушерства та гінекології №1 Національної медичної академії післядипломної освіти

ім. П.Л. Шупика

ORCID: 0000-0002-5524-4411

\section{Ю.В. СЛОБОДЯН}

клінічний ординатор кафедри акушерства та гінекології №1 НМАПО ім. П.Л. Шупика

ORCID: 0000-0002-0478-1436

\section{М.А. БУДЧЕНКО}

клінічний ординатор кафедри клінічний ординатор кафедри акушерства та гінекології №1 НМАПО ім. П.Л. Шупика

ORCID: 0000-0003-3053-3249

Контакти:

Голяновський Олег Володимирович Київський обласний центр охорони здоров'я матері та дитини,

кафедра акушерства та гінекології № 1 НМАПО ім. П.Л. Шупика 04107, Київ, Багговутівська, 1 тел.: +38 (044) 4894935 $+38(067) 7417768$

e-mail:Golyanovskyy@bigmir.net

\section{ВСТУП}

Запальні захворювання жіночих статевих органів (33ЖСО) - дуже актуальна медична проблема, яка суттєво впливає на здоров'я мільйонів жінок дітородного віку та посідає перше місце в структурі гінекологічної патології. Частота цієї групи захворювань, за даними MO3 України, становить від 60 до 80\% у структурі гінекологічної захворюваності населення [2].

Несвоєчасне та неадекватне лікування 33ЖСО призводить до хронізації процесу, що становить серйозну небезпеку внаслідок значної кількості ускладнень, які виникають на фоні цієї патології та можуть спричинити безпліддя, позаматкову вагітність, синдром хронічного тазового болю [7].

\section{АНАЛІЗ ЛІТЕРАТУРНИХ ДАНИХ ТА}

ПОСТАНОВКА ЗАВДАННЯ ДОСЛІДЖЕННЯ

В основі розвитку та формування запальних захворювань лежать взаємопов'язані процеси, які починаються з гострого запалення та закінчуються деструктивними змінами. Основним пусковим механізмом запального процесу жіночих статевих органів $€$ бактеріологічна інвазія, а розвиток запалення визначається мікробним фактором [1,8].

Етіологічна структура неспецифічних 33ЖСО різноманітна. Основними збудниками $є$ різні види стафілококів (золотистий, епідермальний, піогенний та ін.), стрептококи (насамперед групи В), кишкова паличка, вульгарний протей, ентерококи, клебсієла, анаеробні бактерії (бактероїди, пептококи, пептострептококи), гарднерели, дріжджоподібні гриби роду Candida, актиноміцети та інші мікроорганізми. Анаеробні мікроорганізми - причина інфекційно-запальних захворювань органів черевної порожнини і малого тазу в 20,2\% випадків [1].

Згідно із сучасними даними, все більшого значення у виникненні 33ЖСО набувають асоціації мікроорганізмів (стафілококів, анаеробів, стрептококів). Полімікробні асоціації мають місце у 96,7\% хворих із домінуванням у 73,3\% випадків умовно-патогенної мікрофлори (кишкова паличка, ентерокок, епідермальний стафілокок) і анаеробів-бактероїдів [3, 5].

Особливо тяжкий перебіг мають гострі запалення та загострення хронічних запалень внутрішніх жіночих статевих органів, такі як метрити та аднексити, що можуть супроводжуватись гнійними ускладненнями (пельвіоперитоніт, тубооваріальні абсцеси) та потребують хірургічного лікування.

Незважаючи на застосування нових медикаментозних препаратів, тенденції до зниження частоти З3ЖСО не спостерігається. Останній факт спрямовує до пошуку та впровадження нових препаратів та схем лікування [5].

Першим та основним кроком у лікуванні 33ЖСО є адекватна антибактеріальна терапія, яка враховує вид збудника чи збудників та тяжкість перебігу процесу. Відносно вибору оптимальних режимів антибактеріальної терапії за різних форм гінекологічної інфекції, особливо до отримання результатів мікробіологічного дослідження, єдиного погляду немає. Емпірична антибактеріальна терапія базується на даних про полімікробну етіологію абдомінальної інфекції за участю кишкової па- 
лички, ентеробактерій і анаеробних мікроорганізмів. Таке лікування є особливо актуальним у невідкладній гінекології і передбачає якомога раніше призначення ефективних антибіотиків, ще до отримання мікробіологічного підтвердження етіологічного фактора.

Враховуючи сучасні дані стосовно етіології захворювання, препаратами вибору $\epsilon$ комбіновані антибактеріальні засоби, що діють на аеробні та анаеробні мікроорганізми. Також особливе значення має шлях введення препарату: інфузійні та ін'єкційні форми мають кращу біодоступність, їхнє застосування забезпечує швидке досягнення необхідної концентрації діючої речовини в плазмі крові [6].

Для лікування гострих та підгострих запальних процесів матки та її придатків, передопераційної підготовки та супроводу операцій з приводу гнійних процесів жіночих статевих органів ми використовували сучасний комбінований антибактеріальний препарат, що має найширший спектр дії грандазол. 1 мл розчину грандазолу містить левофлоксацину 2,5 мг та орнідазолу 5 мг. Під спектр його дії підпадає більшість відомих представників грампозитивної, грамнегативної, анаеробної, атипової патогенної флори, а також найпростіших.

Фармакологічна дія левофлоксацину - антибактеріальна (бактерицидна). Він переважно впливає на грамнегативні та деякі грампозитивні мікроорганізми: Citrobacter diversus, Enterobacter aerogenes, Escherichia coli, Klebsiella pneumoniae, Proteus mirabilis, Pseudomonas aeruginosa, Citrobacter diversus, Neisseria gonorrhoeae, Chlamydia trachomatis, Staphylococcus aureus, Streptococcus pyogenes. Ефективний щодо мікроорганізмів, стійких до більшості антибіотиків, та сульфаніламідних препаратів, резистентних до $\beta$-лактамних і макролідних антибіотиків.

Фармакологічна дія орнідазолу - антибактеріальна та антипротозойна. Активний щодо Trichomonas vaginalis, Entamoeba histolytica та Giardia lamblia (Giardia intestinalis), a також щодо деяких анаеробних бактерій (Clostridium spp., Bacteroides spp., Fusobacterium spp.) та анаеробних коків.

Широкий спектр дії грандазолу, який не має аналогів, дозволяє ефективно впливати на мікроорганізми емпірично (без попереднього мікробіологічного дослідження), а також застосовувати препарат як монотерапію при поєднаних інфекціях (коли є декілька збудників захворювання) [4].

На початку терапії зазвичай використовують розчин для внутрішньовенного введення, який вводять повільно, шляхом інфузії. Тривалість введення одного 100 мл флакона розчину грандазолу повинна становити щонайменше 60 хвилин.

Через декілька днів, відповідно до стану пацієнтки, можливий перехід від внутрішньовенного введення до перорального прийому з тим же дозуванням. Тривалість лікування залежить від перебігу хвороби. Як і при застосуванні інших антибактеріальних засобів, рекомендують продовжувати лікування препаратом грандазол принаймні протягом 48-72 годин після нормалізації температури тіла або мікробіологічно підтвердженої елімінації збудників.

Мета проведеного дослідження - вивчення ефективності антибіотикотерапії з використанням комбінації левофлоксацину та орнідазолу (препарат грандазол) порівня- но $з$ традиційною комбінованою протимікробною терапією при запальних захворюваннях жіночих внутрішніх статевих органів.

\section{МАТЕРІАЛИ ТА МЕТОДИ ДОСЛІДЖЕННЯ}

На базах кафедри акушерства та гінекології №1 НМАПО ім. П.Л. Шупика було обстежено і проліковано 79 жінок віком від 19 до 40 років із гострими запальними захворюваннями внутрішніх статевих органів.

Основна група складала 40 жінок, контрольна - 39. Обидві групи були репрезентативними за віком, соматичним та гінекологічним анамнезом, а також клінічною картиною захворювання. При обстеженні пацієнток з'ясовували скарги, анамнез захворювання, статевий анамнез. Проводили огляд зовнішніх статевих органів, огляд у дзеркалах, бімануальне обстеження внутрішніх статевих органів та УзД органів малого тазу.

Усі пацієнтки скаржились на біль у нижньому відділі живота, підвищення температури тіла до 37,9-39, ${ }^{\circ} \mathrm{C}$, посилення виділень зі статевих шляхів, болючість під час статевого акту. Під час бімануального вагінального дослідження спостерігали болючість при пальпації матки і придатків, а також болісні тракції за шийку матки. В аналізі крові в дослідній групі визначався лейкоцитоз 12,7 \pm 1,7 × 10\%/л, в контрольній - 13,1 $\pm 2,4 \times 10^{9}$ /л. Початок і перебіг захворювання вкладалися в клінічну картину гострого метро-, ендометриту чи аднекситу або загострення цих хронічних хвороб.

Як етіотропну терапію жінки основної групи отримували 100 мл грандазолу, що містить 250 мг левофлоксацину та 500 мг орнідазолу, 1 раз на добу внутрішньовенно краплинно протягом 3-х днів з подальшим переходом на таблетовану форму з 4-ї доби. Препарат призначали в комбінації з нестероїдними протизапальними засобами в ректальних супозиторіях (диклоберл 100 мг), антимікотичними засобами в профілактичних дозах (флуконазол), полівітамінами, пре- та пробіотиками.

Пацієнтки контрольної групи отримували лікування за загальноприйнятою схемою (цефтриаксон 1 г внутрішньом'язево кожні 12 годин протягом перших 3-х діб з подальшим зниженням дози до 1 г на добу + метронідазол 500 мг перорально двічі на день). Курс терапії становив 10 діб. Лікування проводили під контролем біохімічних та загальноклінічних показників.

\section{РЕЗУЛЬТАТИ ДОСЛІДЖЕННЯ ТА ЇХ ОБГОВОРЕННЯ}

В основній групі дослідження, де як антибактеріальну терапію застосовували комбінацію левофлоксацину і орнідазолу, ми спостерігали швидше зменшення ступеня вираженості симптомів 33ЖСО, нормалізацію температури тіла, зменшення лейкоцитозу та клінічних ознак запалення. Значне покращення самопочуття хворих цієї групи відбувалося вже наприкінці 2-3-ї доби лікування, на відміну від хворих контрольної групи, в яких зменшення больового синдрому, нормалізацію температури тіла і загального самопочуття спостерігали на 5-ту добу терапії.

В основній групі середня температура тіла до лікування становила $38,2 \pm 0,5^{\circ} \mathrm{C}$, на 3-й день терапії вона знижувала- 


\section{ГІНЕКОЛОГІЯ}

ся до $36,8 \pm 0,3{ }^{\circ} \mathrm{C}$. В контрольній групі ці показники становили $38,2 \pm 0,4{ }^{\circ} \mathrm{C}$ та $37,1 \pm 0,3{ }^{\circ} \mathrm{C}$ відповідно.

Рівень лейкоцитів на 3-й день лікування знизився до 9,0 \pm 0,3 × 109 /л в основній групі та до 9,1 \pm 0,3 × 109/л у контрольній; на 7-й день лікування лейкоцитоз в обох групах був відсутній. Показники клінічного одужання становили 96\% для комбінації левофлоксацин + орнідазол та 85\% для комбінації цефтриаксон + метронідазол.

3 жінки основної групи і 2 контрольної були прооперовані у зв'язку з гнійними тубооваріальними пухлинами придатків матки (піосальпінкси, піоовари). В післяопераційному періоді на 3-тю добу хворим контрольної групи через клінічну неефективність антибактеріальної терапії (цефтриаксон + метронідазол) режим антибактеріальної терапії був з успіхом змінений на комбінацію левофлоксацин + орнідазол. Такий клінічний ефект у післяопераційному періоді в обох групах ми пов'язували із ширшим антибактеріальним спектром дії комбінованого антибіотика грандазол. Усі прооперовані жінки були виписані в задовільному стані із заживленням післяопераційної рани per primam на 10-ту добу після операції для реабілітації під наглядом лікаря акушера-гінеколога жіночої консультації.

Таким чином встановлено, що терапія грандазолом мала кращу клінічну ефективність при запальних захворюваннях матки та її придатків порівняно з комбінацією цефтриаксон + метронідазол. На наш погляд, такого ефекту було досягнуто у зв'язку з широким спектром антибактеріальної дії, невеликою кількістю побічних ефектів, зручністю внутрішньовенного введення комбінованого препарату (1 раз на добу).

\section{ВИСНОВКИ}

Проведене дослідження показало високу ефективність препарату грандазол для лікування гострих 33ЖСО або загострень хронічних захворювань цього типу, а також у жінок із гнійними процесами органів малого тазу, а саме: покращення загального стану та зменшення больового синдрому вже на третю добу застосування, нормалізація лабораторних показників, зниження температури тіла аж до повної її нормалізації після 2-3 інфузій препарату.

Крім того, ми відзначили зменшення кількості призначень антибактеріальних препаратів і днів перебування в стаціонарі, що має також і економічний ефект. Зручність використання (1 раз на добу), швидка позитивна динаміка стану хворих дозволяють рекомендувати грандазол як лікарський препарат для емпіричної антибактеріальної терапії З3ЖСО.

\section{ЛITEPATYPA/REFERENCES}

\section{1. Ершов, Г.В.}

Этиологическая структура и резистентность возбудителей воспалительных заболеваний органов малого таза у женщин / Г.В. Ершов, Д.Н. Бочкарев, И.В. Смоленов // Клиническая микробиология и антимикробная химиотерапия. - 2004. - № 6 (2). - С. 201-203.

Ershov, G.V., Bochkarev, D.N., Smolenov, I.V.

"Etiological structure and resistance of pathogens of inflammatory diseases of the pelvic organs in women." Clinical Microbiology and Antimicrobial Chemotherapy 6.2 (2004): $201-3$.

2. Жилка, Н.О., Іркіна, Т.К., Степаненко, В.А.

Стан репродуктивного здоров'я в Україні (медико-демографічний огляд). - К., 2001. - 68 с.

Zhylka, N.0., Irkina, T.K., Stepanenko, V.A.

Reproductive health in Ukraine (medical and demographic surveys). Kyiv (2001): $68 \mathrm{p}$.

3. Зуев, В.М., Педдер, В.В., Полякова, 0.Б.

Неинвазивные технологии лимфогенной терапии сальпингоофорита с применением озоно-ультразвукового метода / В.М. Зуев, В.В. Педдер, 0.Б. Полякова // Вопр. акушерства, гинекологии и перинатологии. - 2004. - № 3 (6). - С. 68-75.

Zuev, V.M., Pedder, V.V., Polyakova, O.B.

"Non-invasive technologies of lymphogenic therapy of salpingoophoritis with ozone-ultrasonic method." Questions of Obstetrics, Gynecology and Perinatology 3.6 (2004): 68 -75.

4. Методики діагностики, лікування і профілактики інфекцій, які передаються статевим шляхом».

Наказ М03 України №312 від 08.05.2009 p.

"Diagnostics, treatment and prevention methods for prophylaxis of sexually transmitted infections."

Order of the MOH of Ukraine from 08.05.2009 №312.

5. Сметник, В.П.

Неоперативная гинекология: Руководство для врачей. - М.: Медицинское информационное агентство. - 2003. - 560 с.

Smetnik, V.P.

Non-operative gynecology: guidelines for physicians. Moscow. Medical Information Agency (2003): $560 \mathrm{p}$.

6. Appelbaum, P., Hunter, P.

"The fluoroquinolone antibacterials: past, present and future perspectives." Int J Antimicrob Agents 16 (2000): 5-15.

7. Brunham, R.C., Binns, B., Guijon, F., et al.

"Etiology and outcome of acute pelvic inflammatory disease."J Infect Dis 158 (1988): 510-7.

8. Centers for Disease Control and Prevention.

"Sexually transmitted diseases: Treatment guidelines 2002." MMWR 51.RR-6 (2002): 1-84. Available from: [http://www.cdc.gov/mmwr/PDF/rr/rr5106.pdf], last accessed Aug 22, 2016. i 


\section{КЛІНІЧНА ЕФЕКТИВНІСТЬ СУЧАСНОї АНТИБІОТИКОТЕРАПІЇ ПРИ ЗАПАЛЬНИХ ЗАХВОРЮВАННЯХ МАТКИ ТА ЇЇ ПРИДАТКІВ}

О.В. Голяновський, д. мед. н., професор кафедри акушерства та гінекології №1 НМАПО ім. П.Л. Шупика

Ю.В. Слободян, клінічний ординатор кафедри акушерства та гінекології №1 нМАПО ім. П.Л. Шупика

М.А. Будченко, клінічний ординатор кафедри акушерства та гінекології №1 нМАПО ім. П.Л. Шупика

У статті розглянуті питання ефективності антибіотикотерапії з використанням комбінації левофлоксацину та орнідазолу (препарат грандазол) порівняно 3 традиційною комбінованою протимікробною терапією при запальних захворюваннях жіночих внутрішніх статевих органів.

Було обстежено і проліковано 79 жінок віком від 19 до 40 років із гострими запальними захворюваннями внутрішніх статевих органів. 0сновна група складала 40 жінок, контрольна - 39. Обидві групи були репрезентативними за віком, соматичним та гінекологічним анамнезом, а також клінічною картиною захворювання.

Як етіотропну терапію жінки основної групи отримували 100 мл грандазолу, в перші три доби одноразово внутрішньовенно з подальшим переходом на таблетовану форму. Препарат призначали в комбінації з нестероїдними протизапальними, антимікотичними засобами в профілактичних дозах, полівітамінами, пре- та пробіотиками. Пацієнтки контрольної групи отримували лікування за загальноприйнятою схемою (цефтриаксон 1 г внутрішньом'язево кожні 12 годин протягом перших трьох діб 3 подальшим зниженням дози до 1 г на добу + метронідазол 500 мг перорально двічі на день). Курс терапії становив 10 діб. Лікування проводили під контролем біохімічних та загальноклінічних показників.

Дослідження показало високу ефективність препарату грандазол для лікування гострих запальних захворювань жіночих статевих органів або загострень хронічних захворювань цього типу, а також у жінок із гнійними процесами органів малого тазу, а саме: покращення загального стану та зменшення больового синдрому вже на третю добу застосування, нормалізація лабораторних показників, зниження температури тіла аж до повноїії нормалізації після 2-3 інфузій препарату. Крім того, зменшилась кількість призначень антибактеріальних препаратів і днів перебування в стаціонарі, що також має й економічний ефект.

Зручність використання (1 раз на добу), швидка позитивна динаміка стану хворих дозволяють рекомендувати грандазол як лікарський препарат для емпіричної антибактеріальної терапії при запальних захворюваннях жіночих статевих органів.

Ключові слова: запальні захворювання жіночих статевих органів, протимікробна терапія, грандазол, левофлоксацин, орнідазол.

\section{КЛИНИЧЕСКАЯ ЭФФЕКТИВНОСТЬ СОВРЕМЕННОЙ АНТИБИОТИКОТЕРАПИИ ПРИ ВОСПАЛИТЕЛЬНЫХ ЗАБОЛЕВАНИЯХ МАТКИ И ЕЕ ПРИДАТКОВ}

О.В. Голяновский, д. мед. н., профессор кафедры акушерства и гинекологии №1 НМАПО им. П.Л. Шупика

Ю.В. Слободян, клинический ординатор кафедры акушерства и гинекологии №1 нмАПО им. П.Л. Шупика

М.А. Будченко, клинический ординатор кафедры акушерства и гинекологии №1 нМАПО им. П.Л. Шупика

В статье рассмотрены вопросы эффективности антибиотикотерапии с использованием комбинации левофлоксацина и орнидазола (препарат грандазол) по сравнению с традиционной комбинированной противомикробной терапией при воспалительных заболеваниях женских внутренних половых органов.

Было обследовано и пролечено 79 женщин в возрасте от 19 до 40 лет с острыми воспалительными заболеваниями внутренних половых органов. Основная группа составляла 40 женщин, контрольная - 39. 0бе группы были репрезентативны по возрасту, соматическому и гинекологическому анамнезу, а также клинической картине заболевания.

В качестве этиотропной терапии женщины основной группы получали 100 мл грандазола, в первые трое суток однократно внутривенно с последующим переходом на таблетированную форму. Препарат назначали в сочетании с нестероидными противовоспалительными, противогрибковыми средствами в профилактических дозах, поливитаминами, пре- и пробиотиками. Пациентки контрольной группы получали лечение по общепринятой схеме (цефтриаксон 1 г внутримышечно каждые 12 ч в течение первых трех суток с последующим снижением дозы до 1 г в сутки + метронидазол 500 мг перорально дважды в день). Курс терапии составил 10 суток. Лечение проводили под контролем биохимических и общеклинических показателей.

Исследование показало высокую эффективность препарата грандазол в лечении острых воспалительных заболеваний женских половых органов или обострений хронических заболеваний этого типа, а также у женщин с гнойными процессами органов малого таза, а именно: улучшение общего состояния и уменьшение болевого синдрома уже на третьи сутки применения, нормализация лабораторных показателей, снижение температуры тела до полной ее нормализации после 2-3 инъекций препарата. Кроме того, уменьшилось количество назначений антибактериальных препаратов и дней пребывания в стационаре, что также имеет и экономический эффект.

Удобство использования (1 раз в сутки), быстрая положительная динамика состояния больных позволяют рекомендовать грандазол как лекарственный препарат для эмпирической антибактериальной терапии при воспалительных заболеваниях женских половых органов.

Ключевые слова: воспалительные заболевания женских половых органов, противомикробная терапия, грандазол, левофлоксацин, орнидазол.

\section{CLINICAL EFFICACY OF MODERN ANTIBIOTIC THERAPY OF THE UTERUS AND UTERINE APPENDAGES INFLAMMATORY DISEASES}

0.V. Golianovskyi, MD, professor of the Obstetrics and Gynecology Department №1, P.L. Shupik National Medical Academy of the Postgraduate Education

Y.V. Slobodian, clinical ordinator of the Obstetrics and Gynecology Department №1, P.L. Shupik National Medical Academy of the Postgraduate Education

M.A. Budchenko, clinical ordinator of the Obstetrics and Gynecology Department №1, P.L. Shupik National Medical Academy of the Postgraduate Education

Questions of efficiency of antibiotic levofloxacin and ornidazole combination (grandazol drug) compared with the traditional combination antimicrobial therapy for inflammatory diseases of the female internal reproductive organs are considered.

Were examined and treated 79 women aged 19 to 40 years with acute inflammatory diseases of organs. The main group was 40 women, control -39 . Both groups are representative for age, physical and gynecological history and clinical disease.

Women of main group received $100 \mathrm{ml}$ grandazol as causal treatment in the first 3 days once intravenously with subsequent transition to tablet form. The drug was administered in combination with nonsteroidal anti-inflammatory drugs, antimycotic drugs in prophylactic doses, multivitamins, pre- and probiotics. Patients in the control group received conventional treatment (ceftriaxone $1 \mathrm{~g}$ intramuscularly every 12 hours during the first three days and then dose decreased to $1 \mathrm{~g}$ per day + metronidazole $500 \mathrm{mg}$ orally twice daily). The therapy course was 10 days. Treatment was carried out under the supervision of general clinical and biochemical parameters.

The study showed high grandazol efficacy for treatment of acute or exacerbation of chronic pelvic inflammatory diseases and purulent processes of the pelvic organs, namely improving the general condition and reduce the pain on the third day of its use, normalization of laboratory values, lower body temperature up to a total normalization after $2-3$ drug infusions. There were fewer antibiotics appointments and days of hospital stay that has economic benefits.

Ease of use (1 per day), fast positive dynamics for patients can be recommended grandazol as a drug for empiric antibiotic therapy of pelvic inflammatory diseases.

Keywords: pelvic inflammatory diseases, antibiotic therapy, grandazol, levofloxacin, ornidazole. 